\title{
Abordagem psicanalítica do sofrimento nas instituições de saúde ${ }^{2}$ Resumo Detalhado
}

\section{Maria Lívia Tourinho Moretto 33}

É com muita alegria que agradeço pelo honroso convite da Sociedade Brasileira de Psicanálise de São Paulo, instituição pela qual eu tenho muito apreço, mas poucas oportunidades para demonstrá-lo.

É uma alegria compartilhar a mesa com a colega Stela Grunberg e, mais uma vez, com Magda, pois o interesse mútuo em nossos trabalhos amplia as possibilidades das boas trocas!

O meu percurso de trabalho enquanto psicanalista nas instituições de saúde (ao longo de um pouco mais trinta anos) e enquanto docente na Universidade (ao longo de quase vinte), ao mesmo tempo que me permitiu a construção de saberes a respeito das possibilidades, dos limites e dos alcances do trabalho do psicanalista nas instituições de saúde, possibilitou-me também a formulação de muitas questões e algumas inquietações que serão apresentadas nesse encontro.

Uma reflexão crítica a respeito das demandas dirigidas ao psicanalista na instituição de saúde indica que a equipe nos convoca quando se depara com dificuldades que emergem do manejo de situações nas quais aquilo que é da ordem da subjetividade atravessa a cena institucional pela via da angústia e/ou do sofrimento, seja do paciente e/ou de seus familiares, seja dos próprios membros da equipe.

De fato, dado o caráter insistente do sofrimento em permanecer em uma cena pouco "equipada" para abordá-lo, as equipes de saúde demandam a nossa presença. O que justifica, portanto, a presença de um psicanalista numa instituição de saúde é, antes de tudo, a presença do sofrimento.

O objetivo principal dessa apresentação é destacarmos e discutirmos a relevância e a pertinência do conceito de sofrimento para a sustentação da experiência do cuidado em Psicanálise nas instituições de saúde, em três

\footnotetext{
${ }^{2}$ Trabalho apresentado na mesa "Clínica psicanalítica: territorios expandidos no II Simpósio Bienal SBPSP "Fronteiras da Psicanálise: a clínica em movimento" no dia 22 de agosto de 2020.

33 Professora titular do IP-USP onde coordena o programa de pós-graduação em Psicologia Clínica, presidente da Sociedade Brasileira de Psicologia Hospitalar.
} 
vertentes, necessariamente interligadas: a vertente clínica, a vertente institucional e a vertente da formação de profissionais da saúde.

Por vertente clínica, entenda-se a experiência do cuidado em Psicanálise por meio do trabalho do psicanalista na abordagem do sofrimento de pacientes adoecidos e/ou seus familiares.

Por vertente institucional, entenda-se a experiência do cuidado em Psicanalise por meio do trabalho no psicanalista na interlocução com os demais campos do saber, portanto, no campo interdisciplinar.

Por vertente da formação de profissionais de saúde, entenda-se a experiência do cuidado em Psicanálise por meio do ensino do psicanalista na Universidade, contribuindo para a formação de profissionais e sua atuação qualificada nas instituições de saúde.

Iniciarei propondo uma reflexão a respeito do processo de adoecimento, destacando a importante diferença entre adoecimento enquanto acontecimento de corpo e adoecimento enquanto experiência singular. Na sequência, apresento algumas narrativas de sofrimento a partir da experiência de adoecimento: perda, fracasso, impotência e trauma. Isso nos permite problematizar o conceito de sofrimento indicando que, em Psicanálise, o sofrimento não é tão somente uma reação aos acontecimentos. Ele está associado, sempre, a uma experiência singular.

Em seguida vamos nos deter no trabalho de análise das demandas endereçadas ao psicanalista na instituição de saúde e de suas respostas nesse contexto. Nesse ponto daremos ênfase às diferenças e às produtivas articulações entre as noções de pedido e demanda, o que nos permitirá examinarmos o arriscado movimento das equipes de saúde no sentido da patologização do sofrimento e, consequentemente, da medicalização do sofrimento, indicando a importância da intervenção do psicanalista nestas situações.

A partir do exposto, apresento uma situação clínico-institucional por meio da qual tornamos evidente que a intervenção do psicanalista é uma aposta que devolve ao "quadro clínico" a dignidade de "caso clínico”.

Ao final, o que se espera é que, por meio da consideração do sofrimento como categoria conceitual, possamos analisar quais problemas concernentes ao campo da saúde podem se resolver a partir da intervenção e da pesquisa 
psicanalítica, quais são os efeitos do trabalho do psicanalista, que diferenças se produzem a partir deles e por quais razões eles interessam à área da saúde.

Os efeitos do trabalho de cada psicanalista podem ser considerados contribuições na medida em que, ao sustentar com clareza os saberes e a ética que legitima sua prática, ele faz das diferenças discursivas o elemento-chave para a análise e resolução de problemas, transformando o seu trabalho em uma oportunidade cuidadosa e privilegiada para a ampliação e avanço do escopo teórico da própria Psicanálise e, consequentemente, para a produção e a transmissão de novos saberes produzidos por meio da pesquisa psicanalítica na área.

Concluímos que se a Psicanálise é o discurso que resguarda o lugar do sujeito, é porque ela sustenta que o sujeito tem algo a dizer que ninguém mais poderia dizê-lo em seu lugar.

Concluímos também que a experiência do psicanalista na Instituição de saúde é um dos modos muito interessantes e abrangentes de ele se engajar no projeto contemporâneo dos cuidados com a vida e que, independente do contexto onde ela acontece, a clínica psicanalítica não é o lugar da aplicação de um saber teórico, mas é o lugar de sua produção. 